Doi: HTTPS://DOI.ORG/10.23910/IJBSM/2018.9.1.3C0431

\title{
Constants in IFD equation for Pandharpur in Scarcity Zone of Western Maharashtra
}

\author{
R. V. Sanglikar ${ }^{1 *}$, S. K. Upadhye ${ }^{1}$, D. D. Pardhe ${ }^{1}$, J. D. Jadhav ${ }^{1}$, V. M. Amrutsagar ${ }^{1}$ and G. Ravindra Chary ${ }^{2}$ \\ ${ }^{1}$ Zonal Agricultural Research Station, Solapur, Mahatma Phule Krishi Vidyapeeth, Rahuri, Maharashtra, India \\ ${ }^{2}$ AICRPDA, CRIDA, Hyderabad, Telengana (500 059), India
}

\section{Corresponding Author}

R. V. Sanglikar

e-mail: sanglikar_rv@rediffmail.com

\author{
Article History \\ Article ID: 3 C0431 \\ Received in $07^{\text {th }}$ October, 2017 \\ Received in revised form $21^{\text {st }}$ December, 2017 \\ Accepted in final form $25^{\text {th }}$ January, 2018
}

\begin{abstract}
The hydrologic phenomena which directly influence the interest of an engineer are rainfall, runoff, flood and drought. The characteristics of rainfall which are of importance for a design engineer are those which are responsible for producing runoff. These characteristics are intensity, duration, frequency of rainfall, time distribution and geographical distribution. Rainfall intensity-frequency-duration equations are required for design of soil and water conservation and runoff disposal structures and for planning flood control projects. The rainfall intensity-duration-return period relationship as $\mathrm{I}=\left(\mathrm{KT}^{\mathrm{a}}\right) /(\mathrm{t}+\mathrm{b})^{\mathrm{d}}$ has been developed for Pandharpur in Solapur district under scarcity zone of Maharashtra. The constants $\mathrm{K}, \mathrm{a}, \mathrm{b}$ and $\mathrm{d}$ in this equation are location specific. The values of parameters a and $\mathrm{b}$ were determined by using graphical method and the values of $K$ and $d$ by least square method. The daily automatic rain gauge charts of Pandharpur for 27 years were analyzed in the form of annual maximum series of various durations viz. 5, 10, 15, 30 minutes, 1, 3, 6, 12 and 24 hours. The constants $\mathrm{K}, \mathrm{a}, \mathrm{b}$ and $\mathrm{d}$ for Pandharpur were found as $3.08,0.2295,0.8$ and 0.9573 respectively by analyzing daily automatic rain gauge charts of Pandharpur. These constants $\mathrm{K}, \mathrm{a}, \mathrm{b}$ and $\mathrm{d}$ are useful in determining the maximum intensity of rainfall which is used in calculation of runoff.
\end{abstract}

Keywords: Rainfall intensity-frequency-duration relationship, IFD, Rainfall intensity

\section{Introduction}

The hydrologic phenomena which directly influence the interest of an engineer are rainfall, runoff, flood and drought. The characteristics of rainfall which are of importance for a design engineer are those which are responsible for producing runoff. These characteristics are intensity, duration, frequency of rainfall, time distribution and geographical distribution. It is not possible to predict accurately the future occurrences of these events from given facts and data in a mathematical manner due to complex nature of hydrologic cycle.

Rainfall is one of the most important factors responsible for soil erosion. The characteristics of rainfall viz., amount, intensity and duration play an important role in determining the rate of soil erosion. Greater the intensity of rainfall, greater is the kinetic energy it possesses. The kinetic energy of rainfall dislodges soil particles and splashes them. Among other factors, the amount of runoff is determined by rainfall intensity, duration and rainfall amount. The rainfall of longer duration reduces the infiltration capacity of soil as result produces considerable runoff regardless of its intensity. The capacity of runoff conveyance system is usually based on certain depth of rainfall to be expected during a selected period of time. Farm terraces, culverts, bridges and flood control structures are thus designed on the basis of safely conveying runoff expected from rain storms of specified frequency, intensity and duration.

The significance of rainfall intensity-duration-return period analysis is also important from economic considerations. An overdesigned structure involves excessive cost and underdesigned structure will be unsafe and also involve high recurring expenditure on repair, maintenance and replacement. An appropriate design would provide a structure with reasonable initial and maintenance cost. In order to have optimization in hydraulic design of any structure, the peak rate of runoff expected during the recurrence interval should be correct. This necessitates the knowledge of rainfall intensityfrequency-duration relationship for a particular location.

The rational formula, which is one of the extensively used empirical formula due to its simplicity, for estimating runoff to be expected from small drainage areas. In USA the generalized charts of rainfall intensity-frequency-duration, developed earlier by Yarnell (1935) and now revised by US Weather Bureau (Hershfield, 1961) are being used for obtaining the value of rainfall intensity ' $\mathrm{I}$ ' in the Rational formula (Ram Babu et al., 1979). Since such generalized charts are not available in our country because of insufficient density of automatic 
raingauge stations, some empirical assumed values of ' $I$ ' are used for estimating runoff which needs improvement. Most of the climate studies carried out in India suggests an increase in trend of both frequency and intensity of extreme events (Meenu et al., 2012; Kannan and Ghosh, 2010).

Rainfall intensity-duration-return period equations on regional basis are required in the country for design of soil conservation and runoff disposal structures and for planning flood control projects. Such relationships and nomographs have been developed at a few stations scattered over the country (Gupta et al., 1968; Raghunath et al., 1969; Khuller et al., 1975 and Senapati et al., 1976). Nemec (1973) developed the general form of the rainfall intensity- duration- return period equation. The constants K, a, b and d for Solapur were found as 11.08 $0.1892,1.01$ and 1.2066 respectively by analyzing 17 years daily automatic rain gauge charts of Solapur (Barai, 2004). These constants $\mathrm{K}, \mathrm{a}, \mathrm{b}$ and $\mathrm{d}$ were modified to $6.96,0.2313$, 1.00 and 1.1081 respectively by analyzing 28 years daily automatic rain gauge charts.(Upadhye et al., 2017).

\subsection{Selection of data}

Jarvis (1936) stated that use of annual maximum value is the most practical rain independent events, which are essential in hydrologic frequency analysis.

Beard (1974) has shown that the relationship between annual series and partial duration series, flood peak varies throughout the U.S. and recommends the use of empirically derived, regionalized relationship. Raghunath et al. (1969), Patel et al. (1969), Kharche (1970), Ram Babu et al. (1979) and Ranade \& Gupta (1988) used the annual duration series method for frequency analysis.

\subsection{Adequacy of length of record}

While analyzing the rainfall data, the adequacy of the length of available record must be ensured for reliable results. Mockus (1960) gave the equation for finding the minimum acceptable years. The values for minimum acceptable years for this study were found less than 28 years for all durations.

\subsection{Method for frequency analysis}

Dalrymple (1960) suggested that for the period of record more than 30 years, the use of mathematical model may be advisable, while for short period of record the graphical method should be preferred.

\subsection{Probability paper}

In order to linearise the frequency distribution, use of probability paper is made. Hazen (1914) suggested the use of probability paper for linearization of normal distribution. The linearization makes the extrapolation or comparison easy. Ram Babu et al. (1979) and Ranade and Gupta (1988) used the log normal probability paper for frequency analysis.

\subsection{Curve plotting}

Ogrosky and Mockus (1957) developed the 'computing method' for plotting the frequency line by computation of plotted points, which was used by Gupta et al. (1968), Handa and Misra (1968), Raghunath et al. (1969), Singh et al. (1971), Sharma (1973) and Ranade and Gupta (1988).

\subsection{Analytical Procedure}

Various equations that were found to represent the rainfall intensity-duration-return period relationship in India and abroad are summarized and discussed by Raghunath et al. (1969). However, the most satisfactory general equation is of the form as given in equation (1).

$1=\frac{K^{\mathrm{a}}}{(\mathrm{t}+\mathrm{b})^{\mathrm{d}}}$

Where,

I = Rainfall intensity, $\mathrm{cm} / \mathrm{hr}$

$\mathrm{T}=$ Return period, $\mathrm{yr}$.

$\mathrm{K}, \mathrm{b}=$ Derived constants

a, d=Derived exponents

\section{Materials and Methods}

Ram Babu et al. (1979) has already worked out intensity duration-return period equations and developed nomographs for the whole country using the relevant data from a large number of raingauge stations. The relationship was developed for Central Zone of India as a whole, which covers a large area. It is necessary to develop such relations which are site specific. In central zone of India the place Solapur is not included. In Maharashtra the values have been determined for Aurangabad, Mahabaleshwar, Mumbai, Nandurbar, Nagpur and Vengurla stations by Ram Babu et al. (1979). Since the relationship between rainfall intensity duration and return period is specific for a particular location and mainly depend upon the physical characteristics of rainfall, the relationship developed for one particular location cannot be superimposed on the other. It is necessary to determine the values of constants $K, a, b$ and $d$ for as many locations as possible. Hence, it is necessary to develop such relationship for small units in order that their reliability and applicability will have greater practical significance. Hence, Barai (2004) analyzed 17 years rainfall data of Solapur upto year 2003 and found the values of constants $K, a, b$ and $d$ as $11.08,0.1892$, 1.01 and 1.1081 respectively. Now, the paper is an effort to find out these constants for Pandharpur in the scarcity zone of Maharashtra by analyzing 27 years data.

\subsection{Location and climate}

The latitude and longitude of Pandharpur are $17^{\circ} 68^{\prime} \mathrm{N}$ and $75^{\circ} 33^{\prime} \mathrm{E}$, respectively. The altitude of raingauge station at Pandharpur is $465 \mathrm{~m}$ above mean sea level. The climate is usually hot and pan evaporation (PE) far exceeds the precipitation and is classified as semi-arid. On an average this station receives annual precipitation of $648.57 \mathrm{~mm}$. The rainfall is scanty, erratic and ill distributed.

\subsection{Data acquisition (Automatic raingauge charts)}


The daily automatic rain gauge charts of Pandharpur for the period 1989 to 2015 (total 27 years) were analyzed for the development of location constants for Pandharpur. The maximum annual rainfall intensities for various durations viz. 5, 10, 15, 30 minutes, 1, 3, 6, 12 and 24 at Pandharpur were obtained from AICRP on Agrometeorology, Solapur center.

\subsection{Collection and preparation of data for analysis}

The daily automatic raingauge charts were analyzed in the form of annual maximum series of various durations viz. 5, $10,15,30$ minutes, 1, 3, 6, 12 and 24 hours.

\subsection{Plotting positions for development of frequency line}

The plotting positions were obtained by using the 'computing method' suggested by Ogrosky and Mockus (1957). The values of antilog of mean, antilog of mean plus and antilog of mean minus are the plotting positions corresponding to 50 per cent, $15.9 \%$ and $84.1 \%$ of abscissa, respectively (Table 1 ).

Table 1 : Plotting positions for development of frequency lines of rainfall intensities of selected durations

\begin{tabular}{lccc}
\hline $\begin{array}{l}\text { Duration, } \\
\mathrm{h}\end{array}$ & \multicolumn{3}{c}{ Rainfall intensity, $\mathrm{mm} / \mathrm{h}$} \\
\cline { 2 - 4 } & $\begin{array}{c}50 \% \text { chance } \\
\text { line }\end{array}$ & $\begin{array}{c}15.9 \% \text { chance } \\
\text { line }\end{array}$ & $\begin{array}{c}84.1 \% \text { chance } \\
\text { line }\end{array}$ \\
\hline 0.08 & 63.79 & 104.12 & 39.08 \\
0.16 & 50.20 & 85.22 & 29.57 \\
0.25 & 44.27 & 77.26 & 25.36 \\
0.50 & 29.51 & 56.62 & 15.38 \\
1.0 & 19.43 & 42.30 & 8.93 \\
3.0 & 10.40 & 19.28 & 5.61 \\
6.0 & 6.77 & 11.04 & 4.16 \\
12.0 & 4.29 & 6.73 & 2.73 \\
24.0 & 2.85 & 4.29 & 1.89 \\
\hline
\end{tabular}

\subsection{Development of frequency line}

The rainfall intensities were plotted on log-normal probability paper, with rainfall intensities on log scale and per cent chance of occurrence on probability scale. A straight line passing through all the three points was extended so that it intersected with ordinate (Figure 1). This line is called as frequency line of rainfall intensity. The frequency lines were drawn for nine durations and are designated as $\mathrm{I}_{0.08}, \mathrm{I}_{0.16}, \ldots \ldots$. and $\mathrm{I}_{24}$ for $0.08,0.16, \ldots \ldots$. and $24.0 \mathrm{~h}$ durations, respectively. The rainfall intensities for each duration against selected per cent frequencies ( $1 \%, 2 \%, 4 \%, 10 \%, 25 \%$ and $50 \%$ ) were obtained. Return period in years was obtained with the help of following equation

$\mathrm{T}=\frac{100}{\mathrm{PC}}$

Where,

$\mathrm{T}=$ Return period, $\mathrm{yr}$.

$\mathrm{PC}=$ Per cent chance.

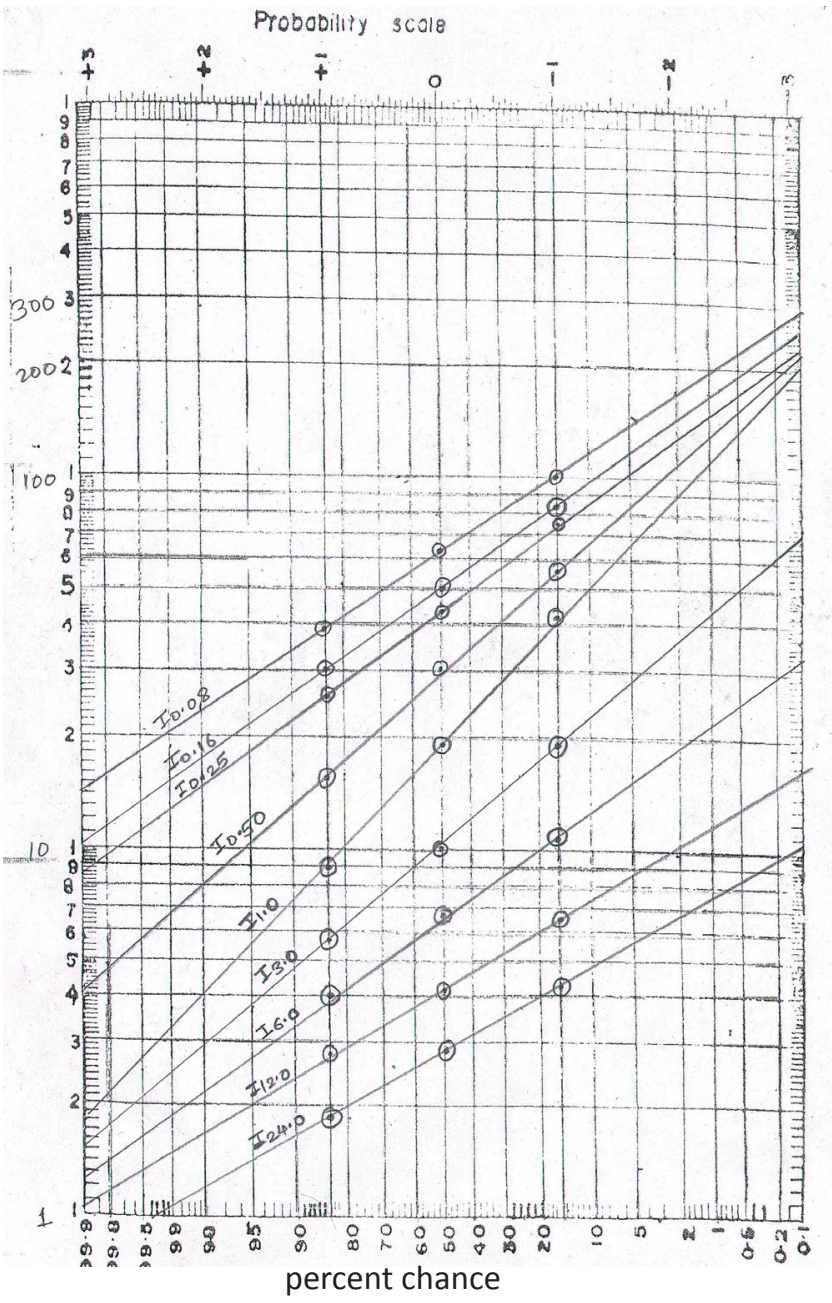

Figure 1: Frequency distribution of rainfall intensities for various durations (log scale $=$ rainfall intensity, $\mathrm{mm} / \mathrm{hr}$, (probability scale $=$ percent chance of occurrence)

The rainfall intensities for selected frequencies and return period for selected durations are given in Table 2.

\subsection{Testing for adequacy of length of record}

The minimum acceptable years of record were determined by using the equation suggested by Mockus (1960). The test works in terms of numbers of years of record used, that is, in terms of sample size. This method is represented by following equation

$Y=\left(4.30 t \log _{10} R\right)^{2}+6$

Where, $Y=$ minimum acceptable years of record

$t=$ Student' $s$ ' $t$ ' at $10 \%$ level of significance

$R=$ Ratio of magnitude of the 100 year event to the 2 year event

The values of $R$ and $Y$ were calculated for all the nine durations and given in Table 3.

The values of ' $Y$ ' for all durations obtained from the test of the length of record are found less than 27 years (Table 3). The 


\begin{tabular}{|c|c|c|c|c|c|c|}
\hline \multirow{5}{*}{$\begin{array}{l}\text { D u ra - } \\
\text { tion, } \mathrm{h}\end{array}$} & \multicolumn{6}{|c|}{ Per cent frequency } \\
\hline & $1 \%$ & $2 \%$ & $4 \%$ & $10 \%$ & $25 \%$ & $50 \%$ \\
\hline & \multicolumn{6}{|c|}{ Return period, year } \\
\hline & 100 & 50 & 25 & 10 & 4 & 2 \\
\hline & \multicolumn{6}{|c|}{ Rainfall intensity, mm/h } \\
\hline 0.08 & 195 & 170 & 130 & 120 & 85 & 64 \\
\hline 0.16 & 160 & 130 & 110 & 100 & 72 & 50 \\
\hline 0.25 & 135 & 120 & 105 & 90 & 60 & 42 \\
\hline 0.50 & 120 & 110 & 88 & 68 & 44 & 30 \\
\hline 1.0 & 110 & 90 & 72 & 50 & 30 & 28 \\
\hline 3.0 & 42 & 37 & 30 & 23 & 15 & 10 \\
\hline 6.0 & 22 & 19 & 16 & 12 & 9 & 6.8 \\
\hline 12.0 & 11.5 & 10.5 & 9 & 7.6 & 5.8 & 4.2 \\
\hline 24.0 & 7.8 & 6.8 & 6 & 5 & 3.8 & 2.8 \\
\hline
\end{tabular}

Table 3: Computation of minimum acceptable years of record (t10 $=1.7171$ at 21 (n-6=27-6=21) d.f.)

Dura- Rainfall Intensity, $R=\log 10 \mathrm{R} \quad \mathrm{Y}=(4.30 \mathrm{t}$

tion, $\mathrm{h} \quad \mathrm{mm} / \mathrm{hr} \quad(2) /(3) \quad \log 10 \mathrm{R}) 2+6$

\begin{tabular}{lccccc}
\cline { 2 - 4 } & $\begin{array}{c}100 \text { year } \\
\text { event }\end{array}$ & $\begin{array}{c}2 \text { year } \\
\text { event }\end{array}$ & & & \\
\hline$(1)$ & $(2)$ & $(3)$ & $(4)$ & $(5)$ & $(6)$ \\
\hline 0.08 & 195 & 64 & 3.05 & 0.48 & 18.82 \\
0.16 & 160 & 50 & 3.20 & 0.51 & 19.97 \\
0.25 & 135 & 42 & 3.21 & 0.51 & 20.08 \\
0.5 & 120 & 30 & 4.00 & 0.60 & 25.85 \\
1 & 110 & 28 & 3.93 & 0.59 & 25.34 \\
3 & 42 & 10 & 4.20 & 0.62 & 27.27 \\
6 & 22 & 6.8 & 3.24 & 0.51 & 20.24 \\
12 & 11.5 & 4.2 & 2.74 & 0.44 & 16.48 \\
24 & 7.8 & 2.8 & 2.79 & 0.44 & 16.84 \\
\hline
\end{tabular}

data analyzed for the present study are of 27 years, hence the length of record considered was found adequate.

In order to evaluate the coefficients $\mathrm{K}, \mathrm{a}, \mathrm{b}$ and $\mathrm{d}$ for frequency curves, the following steps are involved (Ram Babu et al., 1979).

\subsection{Geometric mean slope}

The values of rainfall intensities from table 2 for all durations were plotted on $\mathrm{Y}$-axis and values of return period on $\mathrm{X}$-axis on log-log paper (Figure 2). All the points connected by a thin dotted line giving more weightage to points from 10 year to 100 years return period. The dotted line was extended to cut the $\mathrm{Y}$-axis against 1-year return period. The scale distance of all slope lines was measured from $\mathrm{X}$-axis. The slope of the individual dotted lines for each duration was determined. The geometric mean slope $(\bar{m})$ for the entire set of lines was determined. The geometric mean slope of the lines represents the exponent ' $a$ ' in the equation and found as 0.2295 . The detailed procedure is given in Table 4.

Table 4 : Determination of geometric mean slope of frequency lines or the value of exponent ' $a$ ' in the formula, $\mathrm{I}=\mathrm{K} \mathrm{Ta} /(\mathrm{t}+\mathrm{b}) \mathrm{d}$ at Pandharpur

\begin{tabular}{lcccccc}
\hline $\begin{array}{l}\text { F r e - } \\
\text { quen- } \\
\text { cy lin }\end{array}$ & $\begin{array}{c}\text { Scale distance } \\
\text { (cm) from } \\
\text { X-axis }\end{array}$ & $\begin{array}{c}\text { Diff } \\
\mathrm{B}^{1}\end{array}$ & $\begin{array}{c}\text { length } \\
\text { of Line } \\
\text { AB }\end{array}$ & $\begin{array}{c}\text { Slope } \\
\text { Col 4 / } \\
\text { Col 5 }\end{array}$ & LV \\
1 & 2 & 3 & 4 & 5 & 6 & 7 \\
$\mathrm{I}^{0.08}$ & 14.1 & 10 & 4.1 & 14.9 & 0.2752 & -0.560 \\
$\mathrm{I}^{0.16}$ & 13.7 & 9.7 & 4.0 & 14.9 & 0.2685 & -0.571 \\
$\mathrm{I}^{0.25}$ & 13.2 & 9.5 & 3.7 & 14.9 & 0.2483 & -0.605 \\
$\mathrm{I}^{0.50}$ & 12.5 & 9 & 3.5 & 14.9 & 0.2349 & -0.629 \\
$\mathrm{I}^{1.0}$ & 12.1 & 8 & 4.1 & 14.9 & 0.2752 & -0.560 \\
$\mathrm{I}^{3.0}$ & 9.8 & 6.4 & 3.4 & 14.9 & 0.2282 & -0.642 \\
$\mathrm{I}^{6.0}$ & 8 & 5 & 3.0 & 14.9 & 0.2013 & -0.696 \\
$\mathrm{I}^{12.0}$ & 6.3 & 3.9 & 2.4 & 14.9 & 0.1611 & -0.793 \\
$\mathrm{I}^{24.0}$ & 5.3 & 2.3 & 3.0 & 14.9 & 0.2013 & -0.696 \\
\hline
\end{tabular}

Sum -5.753

Mean $\quad-0.639$

Antilog (Mean) 0.2295

G e o m e tric $\quad 0.2295$

mean slope

Hence the fac- $\quad 0.2295$

tor a

Factor Ta T0.2295

Diff: Difference (col.2-col.3); LV: Logarithmic value of col. 6

\subsection{Rainfall intensity of one year return period}

A line representing the geometric mean slope was drawn at the base through origin as shown in Figure 2. The solid lines parallel to this slope line were drawn by cutting the $y$-axis against 1-year return period. The rainfall intensities against 1-year return period for the corresponding durations are presented in Table 5. The old and new plotting positions are shown in Figure 2.

\subsection{Estimation of constant ' $b$ '}

The values of rainfall intensities of one year return period on $\mathrm{Y}$-axis and selected durations on $\mathrm{X}$-axis plotted on log-log paper (Figure 3). The points so plotted do not fall in a straight line. To make the points aligned into a straight line, suitable constant ' $b$ ' is needed. After adding this constant in the values 


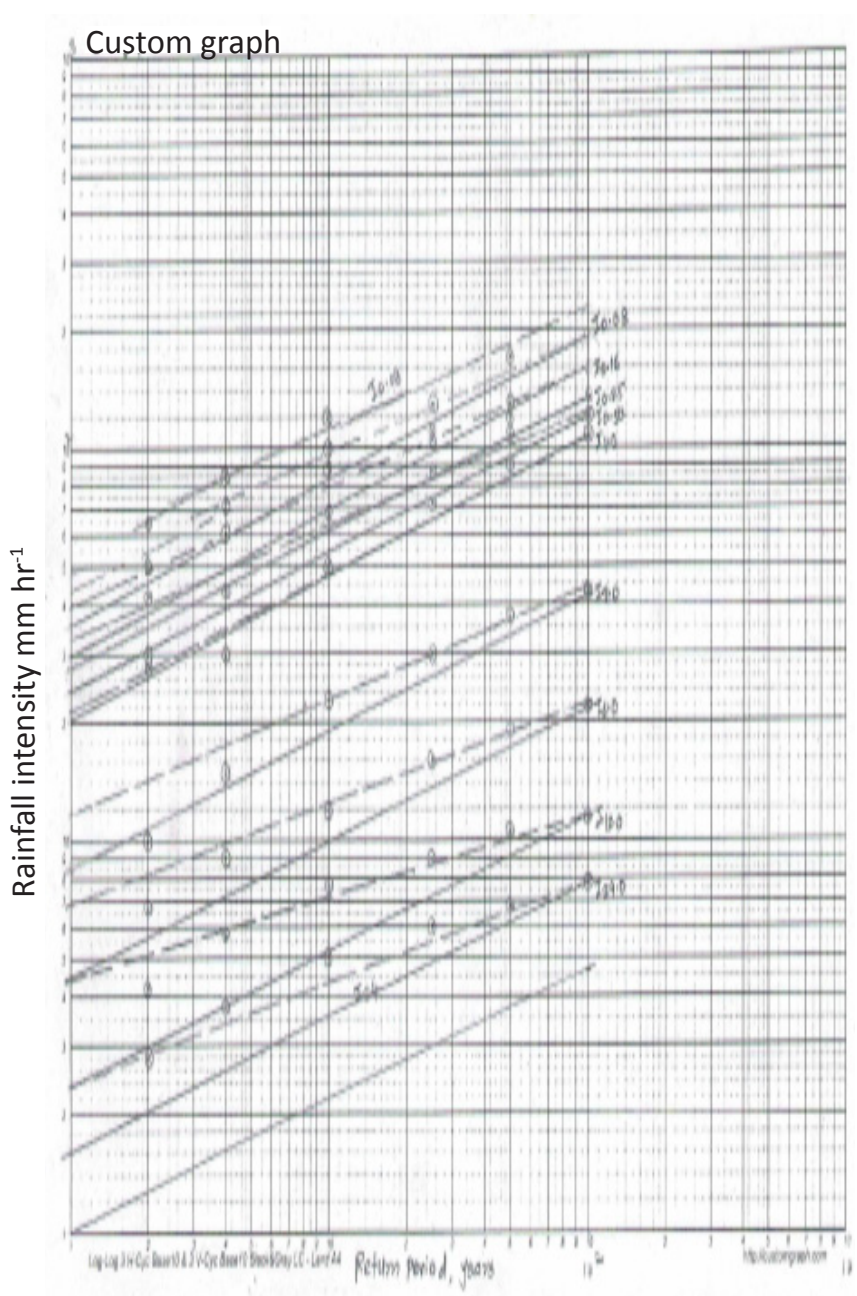

Figure 2: Rainfall intensities for selected durations and return period at Pandharpur

Table 5 : One year rainfall intensity for selected durations at Pandharpur

\begin{tabular}{lc}
\hline Duration, $\mathrm{h}$ & Rainfall Intensity, $\mathrm{mm} / \mathrm{h}$ \\
\hline 0.08 & 36.0 \\
0.16 & 30.0 \\
0.25 & 28.0 \\
0.50 & 24.0 \\
1.0 & 21.0 \\
3.0 & 8.5 \\
6.0 & 4.5 \\
12.0 & 2.4 \\
24.0 & 1.6 \\
\hline
\end{tabular}

of durations the points were aligned into a straight line. The estimated value of ' $b$ ' was 0.8 for Pandharpur.

\subsection{Estimation of constants ' $K$ ' and ' $d$ '}

The constants ' $K$ ' and' $d$ ' are solved by least square method.

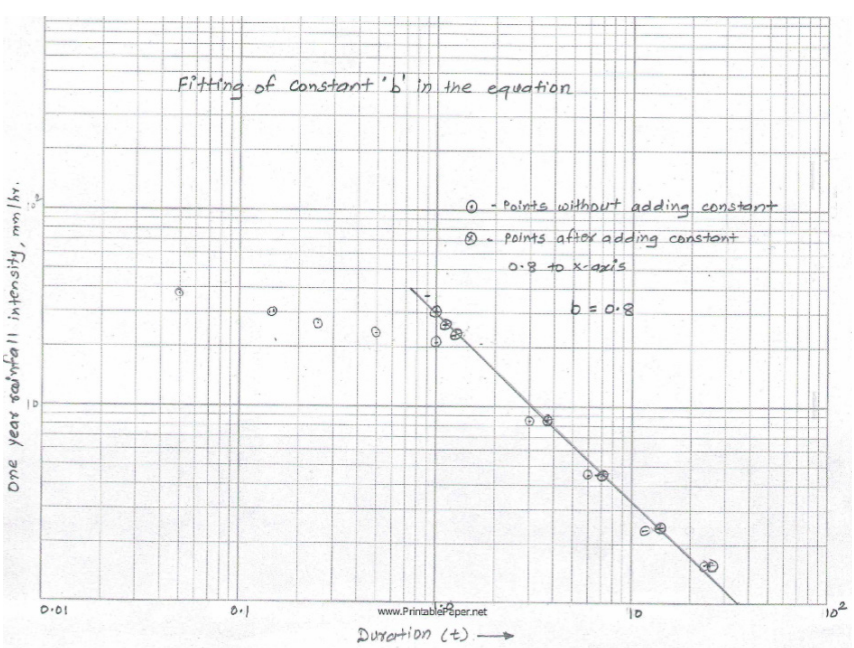

Figure 3: Fitting of constant ' $b$ ' in the equation at Pandharpur

In this method the values of one year ( $T=1$ year) rainfall intensities for selected durations and the values of ' $K$ ' and ' $d$ ' were determined by solving the following equation.

$\mathrm{I}=(\mathrm{K}) /(\mathrm{t}+0.8)^{\mathrm{d}}$

The equation in its logarithmic form can be written as, log I= $\log \mathrm{K}-\mathrm{d} \log (\mathrm{t}+0.8)$, which is in a straight line form.

The constants ' $K$ ' and ' $d$ ' are then solved by least square method by solving the following equations.

$\log k=\frac{\sum \log I \cdot \sum[\log (t+b)]^{2}-\sum[\log \mid \cdot \log (t+b)] \sum \log (t+b)}{n \sum[\log (t+b)]^{2}-\left[\sum[\log (t+b)]^{2}\right.}$

$d=\frac{\left.\sum \log 1 \cdot \log (t+b)\right]-n \sum \log 1 \cdot \log (t+b)}{n \sum[\log (t+b)]^{2}-\left[\sum[\log (t+b)]^{2}\right.}$

By solving above equations, the values of $K$ and $d$ are $K=30.8$ and $d=0.9573$

At this stage, the frequency factor, $\mathrm{T}^{0.2313}$ as obtained, is included to give the rainfall intensity-duration-return period relationship

$I=\frac{3.08 T^{0.2295}}{(t+0.8)^{0.9573}} \mathrm{~cm} / \mathrm{h}$

\section{Results and Discussion}

The constants $K, a, b$ and $d$ in the rainfall-intensity-return period equation developed by analyzing 27 years daily automatic raingauge charts for Pandharpur are 3.08, 0.2295, 0.8 and 0.9573 respectively.

The equation is

$I=\frac{3.08 T^{0.2295}}{(t+0.8)^{0.9573}} \mathrm{~cm} / \mathrm{h}$

Where, I= rainfall intensity, $\mathrm{cm} / \mathrm{hr}$

$\mathrm{T}=$ return period, $\mathrm{yr}$

$\mathrm{t}=$ duration, $\mathrm{h}$ 
By using above equation, the intensity of rainfall for any duration, t upto 24 hours and any return period T upto 100 years can be determined.

\section{Conclusion}

The location constants $K, a, b$ and $d$ in rainfall intensityfrequency-duration relationship for Pandharpur have been recommended as $3.08,0.2295,0.8$ and 0.9573 respectively.

\section{References}

Barai, V.N., 2004. Development of rainfall intensity-durationreturn period equation for Solapur district, Maharashtra. Journal of Soil Water Conservation 3(1\&2), 70-72.

Beard, L.R., 1974. Flood flow frequency techniques. Technical report 119, Center for research in water resources. University of Texas, Austin, Texas.

Dalrymple, T., 1960. Flood frequency analysis. U.S. Geological Survey, Water supply paper, 1543-A, U.S. Dept. of Interior, 80.

Gupta, S.K., Dalal, S.S., Ram Babu, 1968. Analysis of point rainfall data of Deharadun. Irrigation Power Journal 25 (3), 291-300.

Handa, D. P., Misra, P.R., 1968. Studies on rainfall characteristics at Kota. Indian Forester 94(10), 745-752.

Harshfield, D.M., 1961. Rainfall frequency atlas of the United States for durations from 30 minutes to 24 hours and return periods from 1 to 100 years. Engg. Division, Soil Conservation Service, USDA.

Hazen, A., 1914. Storage to be provided in impounding reservoirs for municipal water supply. Transaction of American Society of Civil Engineers 77, 1539-1559.

Jarvis, C.S., 1936. Floods in the United States, magnitude and frequency. U.S. Geological Survey, Water Supply paper 771, 497.

Kannan, S., Ghosh, S., 2010. Prediction of daily rainfall state in a river basin using statistical downscaling from GCM output, Stoch Environ Res Risk Assess (Springer-Verlag), DOI10.1007/s00477-010-0415-y.

Kharche, D.S., 1970. Frequency analysis of rainfall intensities for Vengurla. A thesis for M.Sc. (Agril.) submitted to Mahatma Phule Krishi Vidyapeeth, Rahuri (Unpublished).

Khuller, A. K., Das, D.C., Ram Babu, 1975. Station nomographs and one hour rainfall for intensity-duration-return period computation in India. Soil Conservation Digest $3(2), 1-8$.
Meenu, R., Rehana, S., Majumdar, P.P., 2012. Assessment of hydrologic impacts of climate change in Tunga-Bhadra river basin, India with HEC-HMS and SDSM. Hydrological Process. DOI: 10.1002/hyp.9220.

Mockus, V., 1960. Selecting a flood frequency method. Transaction of American Society of Civil Engineers No.3: 48-51, 54.

Nemec, J., 1973. Engineering Hydrology. Tata McGraw Hill Publishing Co. Ltd., New Delhi.

Ogrosky, H.O., Mockus, V., 1957. National Engineering Handbook Section 4 Hydrology supplement A-18 11 to 14. Soil Conservation Service. USDA.

Patel, A.I., Vanjari, S.S., 1969. Frequency analysis of rainfall intensities for Bombay (Colaba). Journal of Soil and Water Conservation India 17(3 \&4), 24-26.

Raghunath, B., Das, D.C., Lakshmanan, S., 1969. Rainfall intensity-duration-return period analysis and simplified methodology. The Harvestor 11(2), 87-92.

Ram Babu, Tejwani, K.G., Agrawal, M.C., Bhushan, L.S., 1979. Rainfall intensity-duration-return period equations and nomographs of India. Central Soil and Water Conservation Research and Training Institute, Dehradun, Bulletin No.3.

Ranade, D.H., Gupta, R., 1988. Development of Rainfall intensity-Duration-Return period equations for Indore region. Indian Journal of Soil Conservation 16(3), 35-37.

Senapati, P.C., Shakya, S.K., Nema, J.P., 1976. Nomographs of intensity, duration and recurrence interval of rainfall at Bombay (Colaba). Irrigation and Power 33(4), 525-528.

Sharma, S.D., 1973. Nomograph for intensity - duration recurrence interval of rainfall at C.R.R.I., Cuttack. $\mathrm{XI}^{\text {th }}$ Annual Convention of Indian Society of Agrilcultural Engineers Coimbtore.

Singh, A., Shah, C.M., Rajbans, D., 1971. Point rainfall analysis of Soil Conservation Research, Demonstration and Training Center, Vasad (Gujrat). Indian Forester 98(9), 513-519.

Upadhye, S.K., Sanglikar, R.V., Jadhav, J.D., Pardhe, D.D., Amrutsagar, V.M., Rathod, R.K., Ravindra, C.G., 2017. Location Specific Constants in IFD Equation for Solapur Region in Scarcity Zone of Maharashtra. Proceedings of 4th National Confrence on Water, Environment and Society held at JNTU, Hyderabad, 16-24.

Yarnell, D. L., 1935. Rainfall intensity-frequency data, U. S. Deptartment of Agriculture Misc. Publ., 204. 